\title{
Acute haemolytic anaemia associated with polyagglutinability of red cells
}

\author{
T. BIRD AND J. STEPHENSON \\ From the Department of Haematology, Newcastle General Hospital
}

SYNOPSIS A 7-week-old albino infant developed acute haemolytic anaemia following an operation for strangulated inguinal hernia. This was considered to be due to polyagglutinability of the red cells, the haemolysis subsiding as the cells returned to normal. The red cell changes were shown to be due to activation of $\mathrm{T}$-antigen, reacting with anti- $\mathrm{T}$ in the adult blood transfused to the infant.

All human red cells contain hidden antigens in the surface membrane, and one of these, $T$ antigen, can be activated by the action of bacteria or enzymes derived from them. When this occurs the cells are agglutinated by an agglutinin, anti- $T$, present in most sera, but very rare in newborn and very young infants. The original observations were made in cell suspensions infected in vitro by a wide variety of organisms (including $V$. cholerae, Pneumococcus, Streptococcus, and Corynebacteria), and was called the Hübener-Thomsen-Freidenreich phenomenon. Anti-T acts most strongly at low temperatures but can be distinguished from the common cold agglutinins and other antibodies by the fact that it can be absorbed from serum only by 'activated' cells.

Polyagglutinability in vivo is rare, usually associated with severe bacterial infections, but occasionally seen in normal people. It is usually a transient finding, lasting from days to weeks, and of importance only because of possible difficulties in grouping blood, but very occasionally it has been associated with acute haemolysis.

\section{Case Report}

A male albino infant, aged 7 weeks, was admitted with a history of intestinal obstruction for $\mathbf{3 6}$ hours. $\mathrm{He}$ had a strangulated inguinal hernia which was relieved and the hernia repaired. The haemoglobin on admission was $13 \mathrm{~g} / 100 \mathrm{ml}$. During the operation he received $100 \mathrm{ml}$ of whole blood, and next day the haemoglobin was $11 \mathrm{~g} / 100 \mathrm{ml}$. Progress was satisfactory until the fourth day when he became slightly jaundiced. Haemoglobin was $10.4 \mathrm{~g} / 100 \mathrm{ml}$, white cell count $10000 / \mathrm{cmm}$ with neutrophilia, and tests showed no evidence of transfusion reaction. On the Received for publication 8 August 1973. fifth day, haemoglobin was $9 \cdot 1 \mathrm{~g} / 100 \mathrm{ml}$, with $3 \%$ reticulocytes, and a second blood specimen showed polyagglutinability. On the ninth day he was very poorly, haemoglobin had fallen to $4.1 \mathrm{~g} / 100 \mathrm{ml}$, haematocrit was $11 \%$, white cell count was $9000 /$ $\mathrm{cmm}$, and reticulocytes were $15 \%$. The blood film showed anisocytosis, with many normal (transfused cells, $8 \%$ normoblasts, occasional myelocytes, and abundant platelets. No fragmented cells were seen The serum bilirubin was $10 \mathrm{mg} / 100 \mathrm{ml}$, with bilirubir and urobilin in the urine. Serum proteins were only $5 \mathrm{~g} / 100 \mathrm{ml}$, with a decrease in gamma globulin, and other liver function tests were normal. The abdominal wound was infected, and $E$. coli and $B$. proteus were cultured. Eighty $\mathrm{ml}$ of blood was given, the haemoglobin rising to $9.8 \mathrm{~g} / 100 \mathrm{ml}$, and a course of Tetracyn was started. He began to improve, with a decrease in reticulocytes to $2 \%$ and a slow fall in haemoglobin to $8.1 \mathrm{~g} / 100 \mathrm{ml}$, on the twentieth day. He was discharged on the twenty-fifth day. He was seen during the next year and appeared well. He was admitted again at $2 \frac{1}{2}$ years of age with febrile convulsions later thought to be due to epilepsy, with some EEG changes in the left parietal lobe. No blood abnormality was found in repeated examinations.

\section{Serology}

He was grouped as $\mathrm{A} R \mathrm{R}$ positive, with no difficulty at $20^{\circ}$ and $37^{\circ} \mathrm{C}$, and fully compatible blood of the same group was given. When jaundice was reported on the fourth day, the suspect bottle was checked against the original serum and all tests were normal.

On the fifth day a second specimen showed agglutination of the infant's red cells with several anti-B grouping sera at $4^{\circ} \mathrm{C}$ and $20^{\circ} \mathrm{C}$, but not at $37^{\circ} \mathrm{C}$, and the direct Coombs test was negative. 
On the ninth day, when the haemoglobin was $4 \cdot 1$ $\mathrm{g} / 100 \mathrm{ml}$, a third specimen showed agglutination with anti-B sera $44^{\circ} \mathrm{C}, 20^{\circ} \mathrm{C}$, and $37^{\circ} \mathrm{C}$. The infant's serum contained no agglutinins. It was possible to crossmatch another bottle of A Rh-positive blood with a little difficulty while carrying out further tests to determine the abnormality.

The infant's red cells were agglutinated strongly by 10 different anti-B grouping sera and four AB sera at all temperatures. They were also agglutinated by 10 random adult $A B$ and anti-B sera but not by three cord blood sera. The direct Coombs test was positive with several different antihuman globulin sera. Polyagglutination, rather than acquisition of a B antigen (Marsh, 1960), now seemed probable.

Anti-B sera were absorbed with a number of B and $A B$ cells. Following this, they were negative against $B$ and $A B$ cells but still agglutinated, with mixed fields, the infant's cells. Similar results were seen with anti-A sera absorbed with $A$ cells, and agglutination was negative only when the sera were absorbed with the infant's own cells. Absorption with AB-specific substance produced the same results. Activation of $\mathrm{T}$-antigen now seemed most likely. This was confirmed when normal adult sera, known to contain anti-T, were absorbed with adult red cells 'activated' by $V$. cholerae, and did then not agglutinate the infant's cells.

The mother was $A_{2} R h$ positive ( $C D e C D e$ ), the father was $A_{1} R h$ positive (CDe CDe) and the infant was $A_{1} R h$ positive ( $\left.C D e C D e\right)$. The first donor was $A_{1}$ and the second $A_{2}$. Maternal serum showed no agglutination, at $20^{\circ} \mathrm{C}$ and $37^{\circ} \mathrm{C}$, against the red cells of the father, the two donors, and known $A_{1}$ and $A_{2}$ cells, though cold agglutinins were found at $4^{\circ} \mathrm{C}$. It was positive against the polyagglutinable cells of the infant at all temperatures, but not against his cells at a later date. No irregular agglutinins or haemolysins were found in the two donors. The infant's cells were thought to be Coombs positive, but this was shown to be due to anti-T in the antihuman globulin sera. The Donath-Landsteiner and acid-haemolysin tests were negative.

All tests were repeated on the twenty-fourth day and were normal. No evidence of blood disorder was found in the parents.

\section{Discussion}

Polyagglutinability was described, as an almost incidental occurrence, in a 7-week-old infant with autoimmune haemolytic anaemia by Gasser and Hollander (1951). The positive Coombs test could have been due to anti- $T$, which may be present in both broad-spectrum and specific antiglobulin, as in our case. The first well documented case with haemolysis is that of van Loghem, van der Hart, and Land (1955). They described an infant of 4 weeks, with an infected thoracic angioma, who developed polyagglutination and acute haemolysis two days after receiving a transfusion from the father and died in renal failure a few days later. The case reported by Dausset, Moullec, and Bernard (1959) in a male of 65 years with chronic haemolytic anaemıa lasting nine years was due to activation of Tn antigen, a less common cryptantigen which can be separated from $T$ antigen by absorption tests. Six cases were described briefly by van Loghem (1965), including four due to $T$, and two due to Tn, activation. None appeared to be infants and severe bacterial infection was associated in three patients. The most recent case is that of Rickard, Robinson, and Worlledge (1969) in a 14-month-old mongol boy with a respiratory infection.

$T$ antigen can be exposed by neuraminidase, synthesized by many bacteria, which removes neuraminyl groups from the red cell surface. Anti-T, an IgM antibody, which is widespread in normal mammalian sera, is specific for the antigen, and an identical agglutinin can be isolated from peanuts (Arachis hypogaea). Polyagglutinability due to $\mathrm{T}$ antigen can thus be specifically demonstrated by the action of this extract on the red cells, or by the ability of $\mathrm{T}$-activated cells to remove the corresponding antibody without affecting others closely related such as Tn. Details of surface antigens and polyagglutinability have been well reviewed recently by Pardoe and Uhlenbruck (1972).

The polyagglutination and haemolysis in our case appear to be clearly related, with the haemolysis at its height when the polyagglutinability was most marked at $37^{\circ} \mathrm{C}$ and subsiding as the latter disappeared. As in van Loghem's first case, anti-T was almost certainly introduced into the infant's blood by the transfusion and then adsorbed onto the red cells.

It is tempting to suggest that the red cell changes were due to the organisms in the infected abdominal wound but unfortunately tests were not done to prove this. Reepmaker (1952) demonstrated such an association when organisms isolated from the urinary tract were shown to produce polyagglutination in the red cells of the affected patient and others.

There seems to be no reason to suggest a relationship with albinism as this has not been described in any other case.

We wish to thank Miss S. Humphries for secretarial assistance.

\section{References}

Dausset, J., Moullec, J., and Bernard, J. (1959). Acquired hemolytic 
anemia with polyagglutinability of red blood cells due to a new factor present in normal human serum Anti-Tn. Blood, 14, 1079-1093.

Gasser, C., and Hollander, L. (1951). Anémie hémolytique acquise aiguë provoquée par des auto-anticorps, accompagnée de purpura thrombocytopénique, chez un nourrison de 7 semaines. Rev. Hémat, 6, 316-333.

van Loghem, J. J., Jr., van der Hart, M., and Land, M. E. (1955). Polyagglutinability of red cells as a cause of severe hemolytic transfusion reaction. Vox Sang. (Basel), 5, 125-128.

van Loghem, J. J. (1965). Some comments on autoantibody induced red cell destruction. Ann. N.Y. Acad. Sci., 124, 465-476.
Marsh, W. L. (1960). The pseudo B antigen. A study of its development. Vox. Sang. (Basel), 5, 387-397.

Pardoe, G. I., and Uhlenbruck, G. (1972). Cell surface antigens: the $P$ and I blood group systems and some aspects of polyagglutinability. Med. Lab. Tech., 29, 351-378.

Reepmaker, J. (1952). The relation between polyagglutinability of erythrocytes in vivo and the Hübener-Thomsen-Friedenreich phenomenon. J. clin. Path., 5, 266-270.

Rickard, K. A., Robinson, R. J., and Worlledge, S. M. (1969). Acute acquired haemolytic anaemia associated with polyagglutination. Arch. Dis. Childh., 44, 102-105. 